\title{
FEATURES OF ORGANIZATION OF REGIONAL MONITORING OF REPRODUCTIVE HEALTH IN UKRAINE AND ITS RESULTS
}

\author{
Stovban I. V., Marusyn O. V.
}

\section{INTRODUCTION}

Governments of many countries in the European region are constantly monitoring changes in health care service, analyzing the suitability of implementing modern method of approaches to reforming the system of financing the branch, the organization and provision of health care in general. From time to time there are demands to strengthen the control over costs, the necessary conditions for achieving effectiveness, efficiency of health care are discussed in terms of preserving and strengthening the health of the population in combination with ensuring equality and accessibility, fair distribution of necessary medical care among different segments of the population.

The effectiveness of management measures in the field of health care service should be assessed not only in terms of short-term savings of public budget funds, but primarily on the ability of their results to affect the preservation and promoteon of health, in accordance with the WHO strategy "Health for all". The functionning of the health care sector, which has its own regional characteristics in each country, has an extremely wide range of issues related to solutions the most pressing questions, including national policies, in particular prevention of mortality, disability, quality of life, which are global processes and have a long-term potential effect from the implementation of certain reform strategies, and therefore any management decisions in this area must be balanced, science-based, carefully planned and complemented by monitoring the effectiveness of the planned implementation.

Reforming of health care service is driven by economic problems and rising health care costs. There is an ongoing debate between the reasonability for the state to meet the social responsibilities for its compatriots for health care and the reasonability to reduce or curb rising health care costs, with accusations of inefficient spending of small funds that continue to be allocated to health care service. Most countries are characterized by evolutionary gradual changes, although there are examples of radical structural reforms. Many years of discussions on the positive experience of implementing certain strategies in health care service are not completed. Based on the gained experience, the search for constructive alternative strategies for reform continues. At the same time, the percentage of the population of older age groups is growing, the "aging population" continues, the average life expectancy is growing, the level of chronic pathology, its 
comorbidity is growing, the population's health expectations are growing in light of new medical technologies, diagnostic methods and treatment. This emphasizes the relevance of choosing an effective vector for the implementation of sciencebased management measures to achieve a significant positive medical and social effect, especially in preserving and increasing human asset, in this regard, the direction of maternal and child health care is one of the most promising.

\section{Features of the dynamics of certain medical and demographic indicators of Ukraine, which characterize the state of health of the population}

The population of Ukraine continues to decline mainly due to the significant predominance of mortality over birth rate, the natural population growth remains negative (Fig. 1).

For Ukraine, as a country in the European region, the predominance of the urban population in its general structure remains characteristic (Table 1) (data of the State Statistics Service of Ukraine, published in the statistical collection Distribution of the permanent population of Ukraine by sex and age on January 1, 2019. Kyiv, 2019. 345 p.).

The average age of the population in Ukraine in 2019 was 41.6 years, women -44.0 years, men -38.7 years.

In comparison with the indicators of the countries of Northern Europe (84.9\%), the EU countries (73.6\%) and the countries of the WHO European Region (70.2\%), Ukraine is closer to the CIS countries (64.2\%) in urban population ratio (69.41\%). The lowest percentage of urban population, with a predominance in the structure of the living population of rural residents was found in three western regions of Ukraine: Transcarpathian (urban population $37.09 \%$ or 466,138 people, rural population $62.91 \%$ or 790,664 people); Chernivtsi (urban population $43.2 \%$ or 390,719 people, rural population $56.80 \%$ or 513,655 people); Ivano-Frankivsk (urban population $44.2 \%$ or 606,950 people, rural population $55.80 \%$ or 766,302 people).

The distribution of the population by age groups (Table 2) in Ukraine shows that the ratio of the age group $0-17$ years is $18.1 \%$ (including men $20.06 \%$, women $16.32 \%$ ), almost the same is the age group of 65 years and older (16.8\%, including men $12.15 \%$, women $20.74 \%$ ).

Compared to the CIS countries, where the ratio of the age group of 65 years and older is only $11.3 \%$ (in particular in the Russian Federation 13.5\%), the rate of population aging is faster in Ukraine. At the same time, compared to the countries of Northern Europe (18.6\%), the EU countries (19.0\%), where the percentage of the population aged 65 and over is higher (Switzerland 18.0\%, the Czech Republic 18.1\%, Austria 18.8\%, France 18.9\%, Spain 18.9\%, Latvia $19.3 \%$, Finland $20.3 \%$, Portugal $20.7 \%$, Germany $21.1 \%$, Italy $22.4 \%$ ), - on the contrary, the population of Ukraine is "younger". 


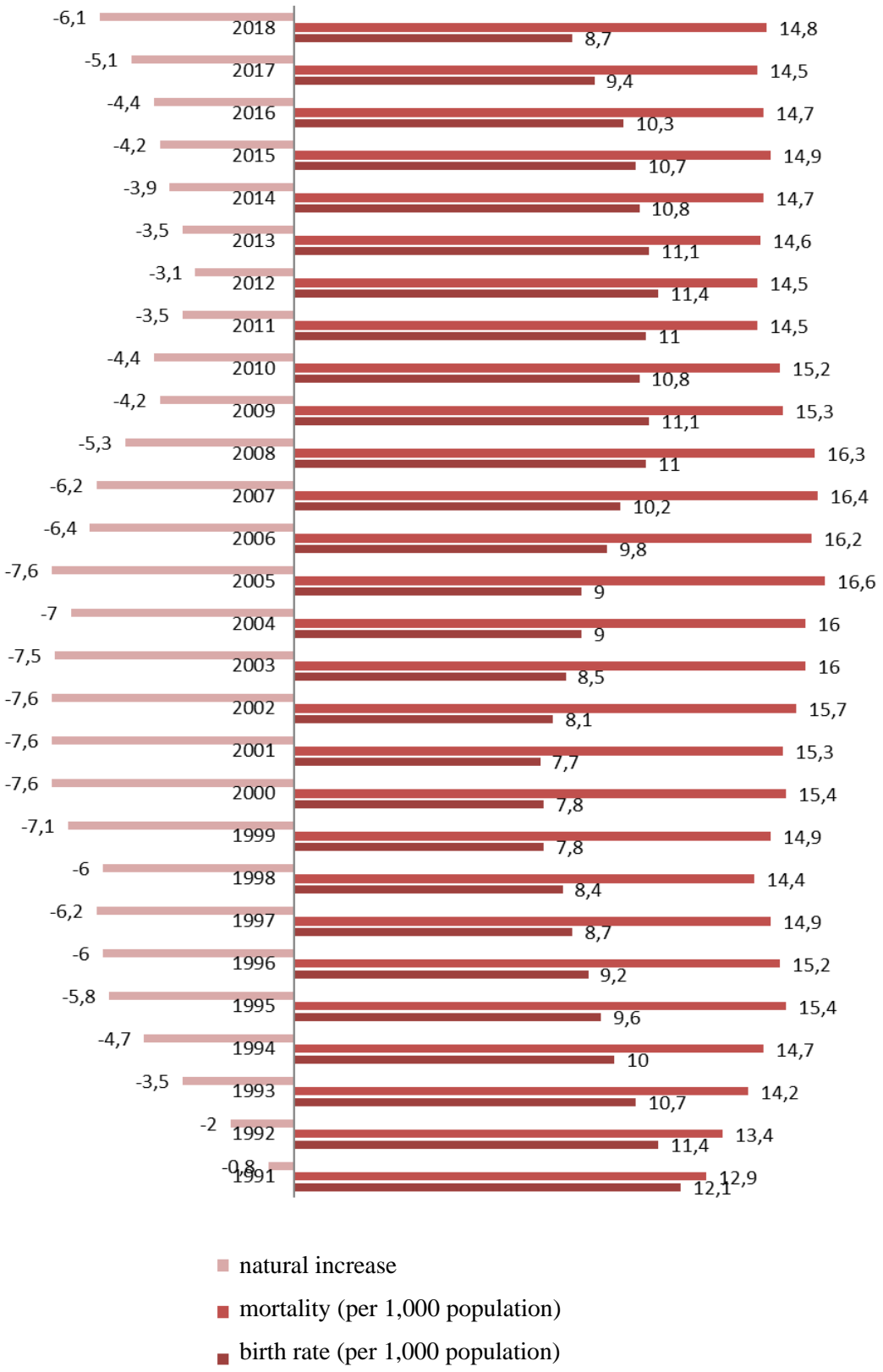

Fig. 1. Dynamics of births, deaths (per 1,000 available population) and natural population growth in Ukraine for the period 1991-2018 
Distribution of the permanent population of Ukraine by place of residence (as of 01.01.2019)

\begin{tabular}{|c|c|c|c|c|c|}
\hline \multirow{2}{*}{ Year } & \multirow{2}{*}{$\begin{array}{c}\text { Population } \\
\text { of Ukraine }\end{array}$} & \multicolumn{2}{|c|}{ Urban population } & \multicolumn{2}{c|}{ Rural population } \\
\cline { 3 - 6 } & 42153201 & 29256696 & $69,41 \%$ & 12896505 & $30,59 \%$ \\
\hline 2019 & 4215 \% & in & Abs. & in\% \\
\hline 2018 & 42386403 & 29370995 & $69,29 \%$ & 13015408 & $30,71 \%$ \\
\hline 2017 & 42584542 & 29479604 & $69,53 \%$ & 13104938 & $30,77 \%$ \\
\hline
\end{tabular}

Table 2

Distribution of the permanent population of Ukraine by age groups and sex (as of January 1, 2019)

\begin{tabular}{|c|c|c|c|c|c|c|}
\hline \multirow{2}{*}{$\begin{array}{c}\text { Age } \\
\text { categories } \\
\text { of the } \\
\text { population }\end{array}$} & \multicolumn{2}{|c|}{ All population } & \multicolumn{2}{|c|}{ Men } & \multicolumn{2}{|c|}{ Women } \\
\hline & Abs. & In \% & Abs. & In \% & Abs. & In \% \\
\hline $\begin{array}{l}0-17 \\
\text { years old }\end{array}$ & 7579703 & $18,1 \%$ & 3903148 & $20,06 \%$ & 3676555 & $16,32 \%$ \\
\hline \begin{tabular}{|l}
$15-64$ \\
years old
\end{tabular} & 28468034 & $67,8 \%$ & 13754231 & $70,70 \%$ & 14713803 & $65,30 \%$ \\
\hline $\begin{array}{l}18 \text { years } \\
\text { and older }\end{array}$ & 34403861 & $81,9 \%$ & 15552124 & $79,94 \%$ & 18851737 & 83,68 \% \\
\hline \begin{tabular}{|l|}
$16-59$ \\
years old
\end{tabular} & 25293695 & $60,3 \%$ & 12391759 & $63,70 \%$ & 12901936 & $57,27 \%$ \\
\hline $\begin{array}{l}60 \text { years } \\
\text { and older }\end{array}$ & 9827110 & $23,4 \%$ & 3529581 & $18,14 \%$ & 6297529 & $27,95 \%$ \\
\hline $\begin{array}{l}65 \text { years } \\
\text { and older }\end{array}$ & 7034551 & $16,8 \%$ & 2363033 & $12,15 \%$ & 4671518 & $20,74 \%$ \\
\hline
\end{tabular}

The problem is the difference between the ratio of men and women, in favour of the latter, in the structure of the adult population (men $-79.94 \%$, women $-83.68 \%$ ) and the population aged 60 years and older (men $-18.14 \%$, women - 27.95\%), 65 years and older (men - 12.15\%, women - 20.74\%). The average age of men (38.7 years) differs significantly from the average age of women (44 years) in Ukraine. At the same time, in spite of the fluctuations, there is a gradual increase in life expectancy at birth, while maintaining the difference in favour of women in both rural and urban areas (Fig. 2, 3).

The difference between the average life expectancy at birth of men (66.69 years) and women (76.72 years) in 2018 was 10 years. The gap between men (65.33 years) and women (76.01 years) living in rural areas was even larger (the difference was more than 10 years). 


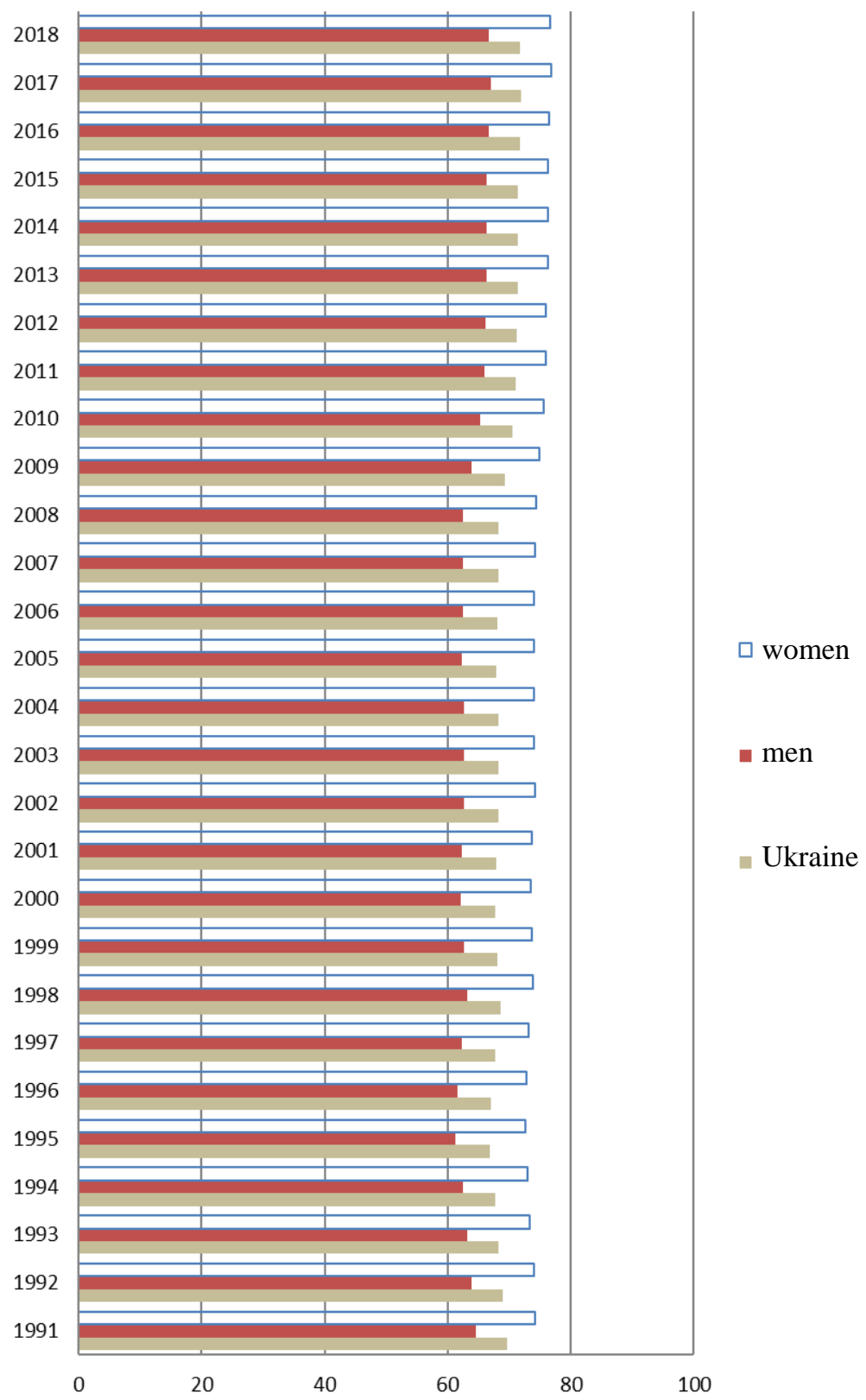

Fig. 2. Dynamics of average life expectancy at birth of the population of Ukraine in years, including by sex for the period 1991-2018 


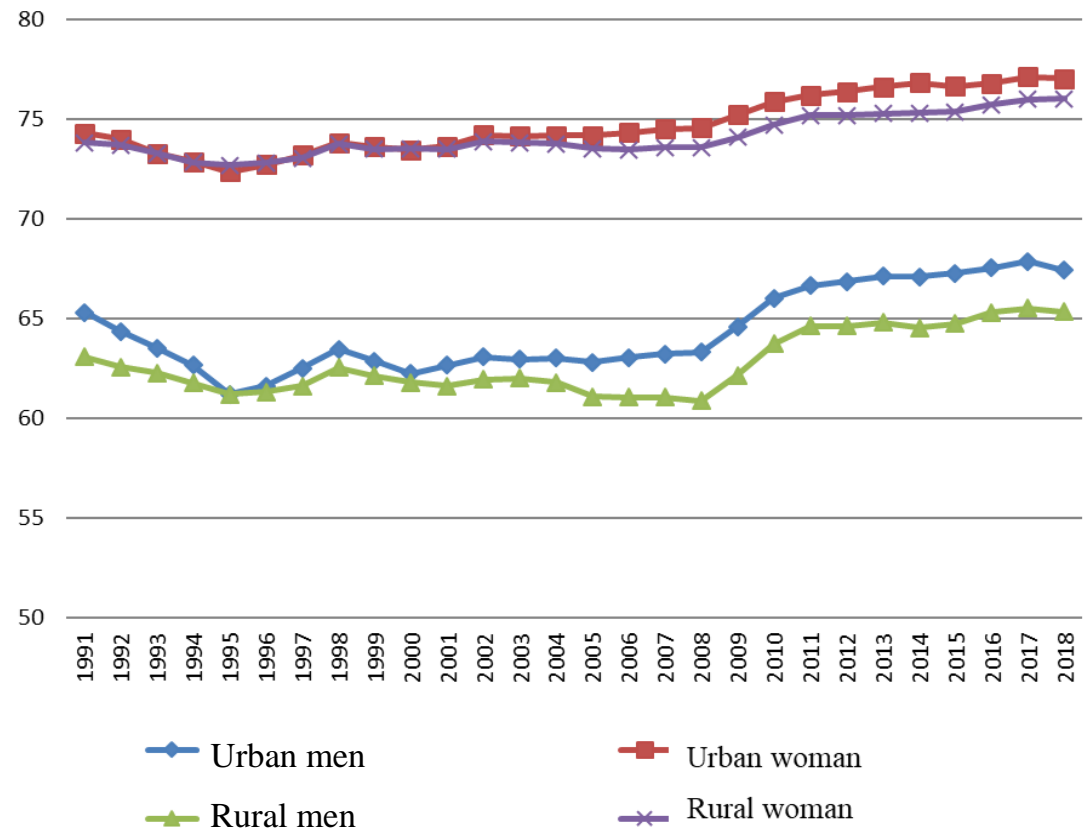

Fig. 3. Dynamics of average life expectancy at birth of the population of Ukraine in years by sex and type of area for the period 1991-2018

Analysis of the dynamics of live births by sex revealed that since 1991, 106 or 107 boys are born per 100 girls almost every year.

The total birth rate per woman in Ukraine in 2018 was 1.301 (1.22 in urban areas and 1.427 in rural areas), it turned out that it remains higher in rural areas (Fig. 4). The identified trends show its gradual decline.

Over the years of the study there have been changes in the structure of live births by age of the mother in years, namely there is a gradual decrease in the proportion of women giving birth under 20 years, with increasing age groups of women 30-34 years and 35-39 years (Fig. 5).

The revealed picture corresponds to modern European tendencies. Thus, the age birth rate of women (the number of live births per 1,000 women of the appropriate age) aged 20-24 years was 156.9 in 1991 and became 73.3 in 2018 (a decrease of 2.1 times) with their growth in the age group women 3034 years (from 37.9 in 1991 to 54.3 in 2018), 35-39 years (from 13.9 in 1991 to 26.4 in 2018), 40-44 years (from 3.1 to 6.1) and even 45-49 years (from 0.1 to 0.7 ). In 2018, the average age of a mother at birth in Ukraine was 25.9 years (26.9 in urban areas, 23.8 in rural areas). 


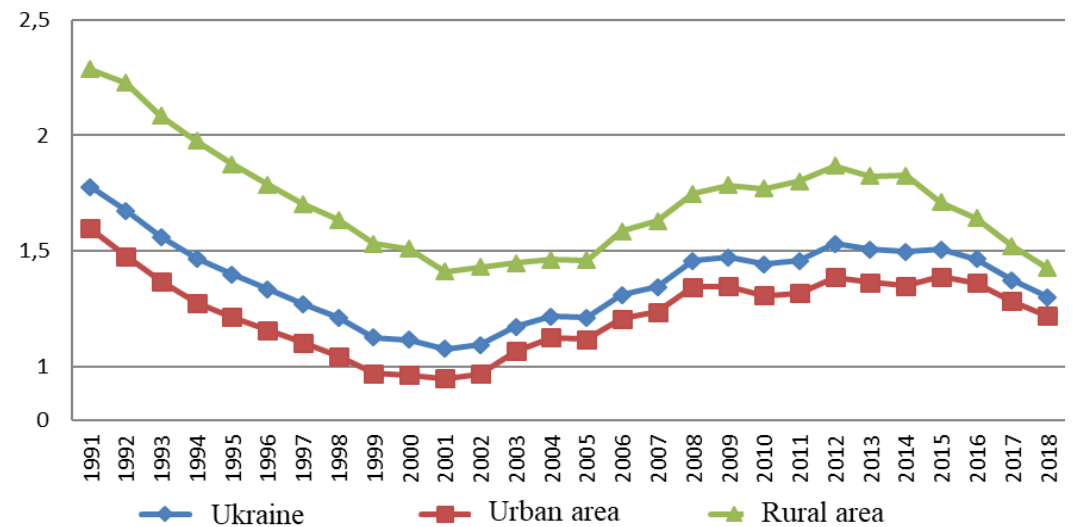

Fig. 4. Dynamics of the total birth rate in Ukraine, including by type of area in 1991-2018

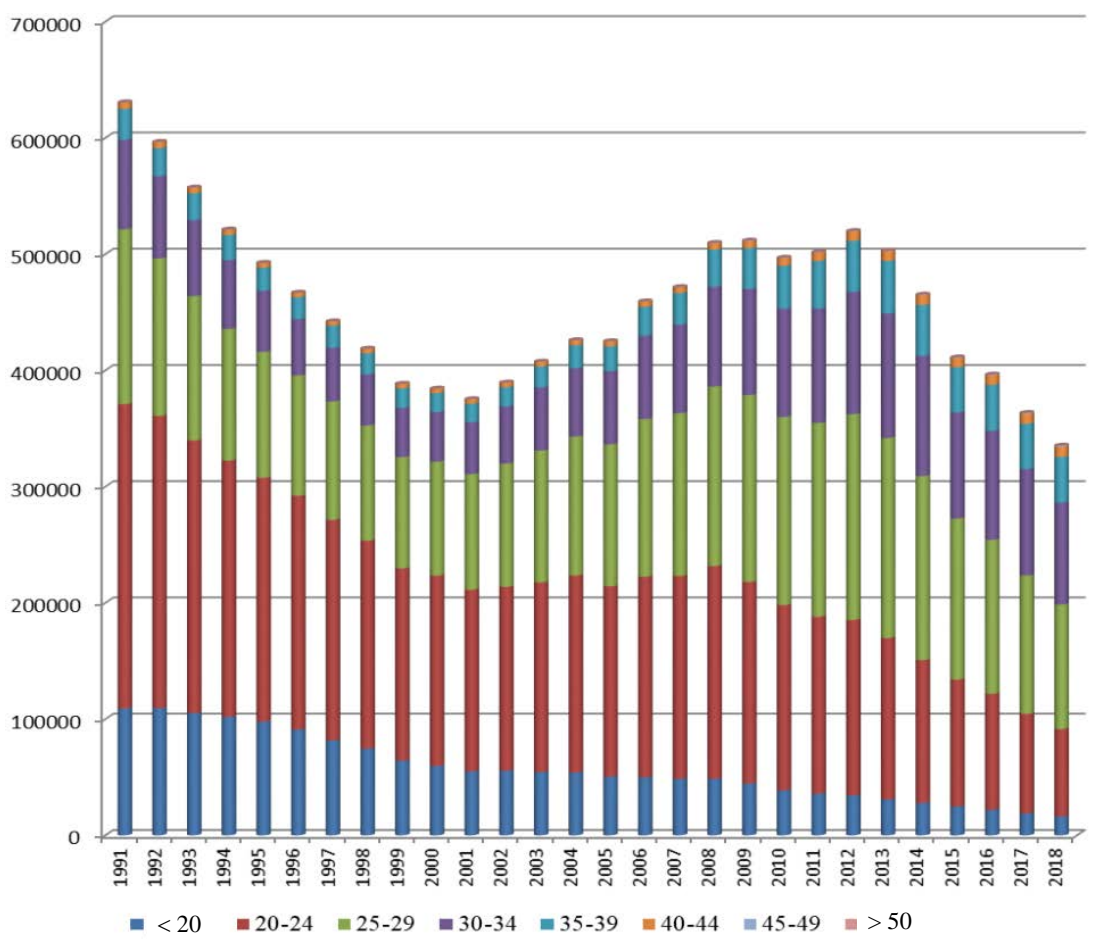

Fig. 5. Dynamics of the number of live births by age of the mother in the years 1991-2018 
Thus, the identified trends indicate a decrease in population mainly due to the predominance of mortality over births, reducing the total birth rate per woman, increasing the proportion of women who give birth in older age (35 years and older), which in turn updates the study of reproductive health and health of newborns in the light of identified trends.

\section{Experience in establishing reproductive health monitoring in the world}

In a situation where the population is growing in most countries, the problems of urbanization, population aging, preservation and strengthening of public health in conditions of environmental degradation, increasing life expectancy of high quality come to forefront; reverse trends in population decline are characterized for Ukraine (from 46.0 million people in 2010 to 42.2 million people in 2019) (Table 3).

Health is a priority in health development strategies and public values. That is why the average life expectancy exceeds 75-80 years in the developed countries (Ireland 80.4; Spain 80.6; Italy 80.8; Cyprus 80.2; Malta 80.2; the Netherlands 80.2; Germany 78.7; France 79.6; Sweden 80.8), while in Ukraine it is 67 years old.

Table 3

International comparisons of the population dynamics of Ukraine with individual EU countries (million people)

\begin{tabular}{|l|c|c|c|c|c|c|c|c|c|c|c|}
\hline & $\mathbf{2 0 1 0}$ & $\mathbf{2 0 1 1}$ & $\mathbf{2 0 1 2}$ & $\mathbf{2 0 1 3}$ & $\mathbf{2 0 1 4}$ & $\mathbf{2 0 1 5}$ & $\mathbf{2 0 1 6}$ & $\mathbf{2 0 1 7}$ & $\mathbf{2 0 1 8}$ & $\mathbf{2 0 1 9}$ \\
\hline \multicolumn{1}{|c|}{1} & 2 & 3 & 4 & 5 & 6 & 7 & 8 & 9 & 10 & 11 \\
\hline Ukraine & $\mathbf{4 6 , 0}$ & $\mathbf{4 5 , 8}$ & $\mathbf{4 5 , 6}$ & $\mathbf{4 5 , 6}$ & $\mathbf{4 5 , 4}$ & $\mathbf{4 2 , 9}$ & $\mathbf{4 2 , 8}$ & $\mathbf{4 2 , 6}$ & $\mathbf{4 2 , 4}$ & $\mathbf{4 2 , 2}$ \\
\hline Austria & 8,4 & 8,4 & 8,4 & 8,5 & 8,5 & 8,6 & 8,7 & 8,8 & 8,8 & 8,9 \\
\hline Belgium & 10,8 & 11,0 & 11,1 & 11,1 & 11,2 & 11,2 & 11,3 & 11,4 & 11,4 & 11,5 \\
\hline United Kingdom & 62,5 & 63,0 & 63,5 & 63,9 & 64,4 & 64,9 & 65,4 & 65,8 & 66,3 & 66,7 \\
\hline Denmark & 5,5 & 5,6 & 5,6 & 5,6 & 5,6 & 5,7 & 5,7 & 5,7 & 5,8 & 5,8 \\
\hline Estonia & 1,3 & 1,3 & 1,3 & 1,3 & 1,3 & 1,3 & 1,3 & 1,3 & 1,3 & 1,3 \\
\hline Ireland & 4,5 & 4,6 & 4,6 & 4,6 & 4,6 & 4,7 & 4,7 & 4,8 & 4,8 & 4,9 \\
\hline Spain & 46,5 & 46,7 & 46,8 & 46,7 & 46,5 & 46,5 & 46,4 & 46,5 & 46,7 & 46,9 \\
\hline Italy & 59,2 & 59,4 & 59,4 & 59,7 & 60,8 & 60,8 & 60,7 & 60,6 & 60,5 & 60,4 \\
\hline Cyprus & 0,8 & 0,8 & 0,9 & 0,9 & 0,9 & 0,8 & 0,8 & 0,9 & 0,9 & 0,9 \\
\hline Luxembourg & 0,5 & 0,5 & 0,5 & 0,5 & 0,5 & 0,6 & 0,6 & 0,6 & 0,6 & 0,6 \\
\hline Malta & 0,4 & 0,4 & 0,4 & 0,4 & 0,4 & 0,4 & 0,5 & 0,5 & 0,5 & 0,5 \\
\hline Netherlands & 16,6 & 16,7 & 16,7 & 16,8 & 16,8 & 16,9 & 17,0 & 17,1 & 17,2 & 17,3 \\
\hline Germany & 81,8 & 80,2 & 80,3 & 80,5 & 80,8 & 81,2 & 82,2 & 82,5 & 82,8 & 83,0 \\
\hline Poland & 38,0 & 38,1 & 38,1 & 38,1 & 38,0 & 38,0 & 38,0 & 38,0 & 38,0 & 38,0 \\
\hline Portugal & 10,6 & 10,6 & 10,5 & 10,5 & 10,4 & 10,4 & 10,3 & 10,3 & 10,3 & 10,3 \\
\hline Slovakia & 5,4 & 5,4 & 5,4 & 5,4 & 5,4 & 5,4 & 5,4 & 5,4 & 5,4 & 5,5 \\
\hline
\end{tabular}


End of Table 3

\begin{tabular}{|l|c|c|c|c|c|c|c|c|c|c|}
\hline \multicolumn{1}{|c|}{1} & 2 & 3 & 4 & 5 & 6 & 7 & 8 & 9 & 10 & 11 \\
\hline Slovenia & 2,0 & 2,1 & 2,1 & 2,1 & 2,1 & 2,1 & 2,1 & 2,1 & 2,1 & 2,1 \\
\hline Hungary & 10,0 & 10,0 & 9,9 & 9,9 & 9,9 & 9,8 & 9,8 & 9,8 & 9,8 & 9,8 \\
\hline Finland & 5,4 & 5,4 & 5,4 & 5,4 & 5,5 & 5,5 & 5,5 & 5,5 & 5,5 & 5,5 \\
\hline France & 64,7 & 65,0 & 65,3 & 65,6 & 66,2 & 66,5 & 66,6 & 66,8 & 66,9 & 67,0 \\
\hline Czech Republic & 10,5 & 10,5 & 10,5 & 10,5 & 10,5 & 10,5 & 10,6 & 10,6 & 10,6 & 10,6 \\
\hline Sweden & 9,3 & 9,4 & 9,5 & 9,6 & 9,6 & 9,7 & 9,9 & 10,0 & 10,1 & 10,2 \\
\hline
\end{tabular}

The predominance of mortality over birth rate provokes a distortion of demographic processes in the country, which contributes to depopulation.

The experience of developed countries, domestic experience convinces in the expediency of developing state and regional comprehensive programs to promote the reproductive health of our nation, increase the birth rate of healthy children. The strategic approach to the realization of this goal includes first of all the assessment of the existing problem from the standpoint of a systematic approach, study and comparison of domestic and foreign experience in the implementation of this research area.

In order to strengthen national health care systems and develop policies in the field of health care in the WHO European Region, it is planned to develop regional programs at the level of member states of the European region, which would be consistent with health priorities in the region and take into account current research and its results. To ensure this function and increase the amount of information on the basis of which it will be possible to adopt constructive programs in the field of health care, it is proposed to develop indicators, metrics, monitoring of which would allow critical assessment of the current situation and strategic planning.

Efficient regional monitoring of reproductive health in the countries of the European region includes indicators: the percentage of live births weighing 2,500 grams and more; the percentage of live births by mothers over 35 years old; percentage of live births by mothers under 20 years of age; frequency of abortions per 1,000 live births; frequency of abortions of mothers under the age of 20 and 35 years and older per 1,000 live births; the number of births with congenital pathology, Down syndrome; the percentage of children who have been immunized; the percentage of children immunized in particular against measles, hepatitis $\mathrm{B}$, mumps, whooping cough, polio, rubella, tetanus, tuberculosis; the percentage of children who were breastfed before 3 months of age (up to 6 months of age); the percentage of births in the presence of qualified medical staff, etc. These indicators are selected as indicative in terms of informativeness and universality of collection, calculation of statistical information and are widely used to assess the state of reproductive health around the world. The proposed universality of the approach allows to 
compare the obtained results in order to form integrated assessments of the identified trends, identify problematic issues and substantiate measures to achieve favourable trends in the formation of reproductive health of the selected area (state, region). Today, the list of indicators for studying the state of reproductive health of the population as in whole in Ukraine and at the level of its regions remains open for study. The question of which of the indicators, or their groups, is the most informative, the one that most accurately reflects the situation, is debatable.

Thus, there are not only doctors and scientists in the country who deal with reproductive health. However, it remains unresolved and needs to be continued and scientifically substantiated in the light of the emergence of new medical technologies, diagnostic, prevention programs, treatment and rehabilitation methods. The existing regional features of the state of reproductive health in the main regions of Ukraine, in particular in its western regions, which have certain regional demographic features with a predominance of the rural population in their structure, need to be studied. For example, compared to the population as a whole in the country, IvanoFrankivsk region has its own characteristics of public health.

\section{CONCLUSIONS}

In Ukraine, there are trends of depopulation due to the predominance of mortality over birth, the total birth rate per woman decreases, the proportion of women (35 years and older) who give birth to children increases, which in turn actualizes the study of reproductive health and the state of health of newborns in light of the identified trends. The existing regional features of the state of reproductive health in the main regions of Ukraine, in particular in its western regions, which have certain regional demographic features with a predominance of the rural population in their structure, need to be studied.

\section{SUMMARY}

The population of Ukraine continues to decline mainly due to the significant predominance of mortality over birth rate, the natural population growth remains negative, the predominance of the urban population in its general structure remains characteristic. The distribution of the population by age groups in Ukraine shows that the ratio of the age group $0-17$ years is $18.1 \%$, almost the same is the age group of 65 years and older. Decrease in population are mainly due to the predominance of mortality over births, reducing the total birth rate per woman, increasing the proportion of women who give birth in older age (35 years and older), which in turn updates the study of reproductive health and health of newborns in the light of identified trends. In order to strengthen national health care systems and develop policies in the field of health care in the WHO European Region, it is planned to develop regional programs at the level 
of member states of the European region. Efficient regional monitoring of reproductive health in the countries of the European region includes different indicators. Today, the list of indicators for studying the state of reproductive health of the population as in whole in Ukraine and at the level of its regions remains open for study. The question of which of the indicators, or their groups, is the most informative, the one that most accurately reflects the situation, is debatable. The existing regional features of the state of reproductive health in the main regions of Ukraine, in particular in its western regions, which have certain regional demographic features with a predominance of the rural population in their structure, need to be studied.

\section{REFERENCES}

1. Штогрин О.П. Нерівність у галузі репродуктивного здоров'я як проблема державного управління. Ефективність державного управління [Текст]. 2014. Вип. 38. С. 9-106.

2. Постанова КМУ № 1849 від 27.12.2006p. Про затвердження Державної програми «Репродуктивне здоров'я нації» на період до 2015 року. URL : https://zakon4.rada.gov.ua.

3. The health and well-being of men in the WHO European Region: better health througha gender approach (2018). URL : http://www.euro.who.int/ data/assets/pdf_file/0007/380716/mhr-report-eng.pdf?ua=1^.

4. Репродуктивне здоров'я населення україни як основний критерій ефективності соціально-економічної політики держави / P.О. Моісеєнко, С.С. Мокрецов, О.О. Дудіна, Н.П. Кризина. Украӥна. Здоров'я наиіï. 2012. № 2(22). С. 86-91.

5. Pillai V, Wang Y.C., Maleku A. Women, war, and reproductive health in developing countries. Soc Work Health Care. 2017; 56(1): 28-44.

\section{Information about authors:} Stovban I. V.,

Candidate of Medical Sciences, Associate Professor of the Department of Social Medicine and Public Health Ivano-Frankivsk National Medical University 2, Galytska str., Ivano-Frankivsk, 76018, Ukraine Marusyn O. V.,

Candidate of Medical Sciences,

Endocrinology Expert of the Department of Health

Ivano-Frankivsk Regional State Administration, Associate Professor of the Department of Endocrinology

Ivano-Frankivsk National Medical University

2, Galytska str., Ivano-Frankivsk, 76018, Ukraine 